\title{
Changes in Financial Markets and Their Effects on Agriculture
}

\author{
C. B. Baker
}

\section{$\mathbf{T}$} 1971 for to an unprecedented $\$ 1,065,441$ million at the end of 1979 , expressed in terms of 1986 dollars. By the end of 1986, proprietor's equity had been about halved to a level only about $\$ 2$ billion more in 1986 dollars than it was at the end of $1959,{ }^{1}$

The total value of farm sector assets in 1986 dollars also peaked in 1979 , at $\$ 1,280,712$ million. Total sector debt did not peak until 1982 , at $\$ 227,615$ million. Farm real estate value peaked as well in 1982 , at $\$ 978,338$ million. It then declined to $\$ 506,791$ million by the end of 1986, only a half mitlion more than it had been at the end of $1965 .^{z}$

Agriculture is affected by changes in both domestic and international financial markets. The changes in financial markets in the past two decades have been dominated by the deregulation of domestic markets, the growth and integration of intemational markets, and the technologies of information management, interacting with the other two changes.

Like all markets, financial markets carry information as well as resolve terms of exchange. Deregulation has reduced the repression of information and has accel-

$\bar{C}$. B. Baker is a professor of agricultural economics at the University of Illinois, Urbana-Champaign. This paper was presented at the annual meeting of the Federal Aeserve System Committee on Agriculture and Rural Development held at the Federal Reserve Bank of St. Louis on May 21, 1987.

'See Melichar (1987).

₹|bid.

erated product innovations and changes in management practices in firancial markets. Such responses have created startling changes in the structure and performance of both domestic and international financial markets, with more doubtless to come.

Agriculture is capital-intensive and export-sensitive. It is affected profoundly, therefore, by interest rates and exchange rates. Interest rates are important to the cost of debt service and the value of durable assets, especially land. Because exchange rates influence the demand for farm exports, they are important to the trade and prices of farm commodities and thus to farm income.

The growth and integration of international financial markets has modified the role of domestic financial markets in channeling the effects of macroeconomic events and macroeconomic management to agriculture. The macroeconomy of the United States interacts with the macroeconomy of other countries in a worldwide system that determines interest rates and exchange rates. The interaction is especially in" tense with countries related to the United States through trade and developmental issues, and involves multilateral financing instirutions as well.

The massive effects outlined in the opening two paragraphs are linked substantially with changes in financial markets. This paper will emphasize the international setting for the linkage, prefaced with a brief review of the role of agriculture in economic development, owing to the importance of economic development issues among factors that bear on the future pefformance of U.S. agriculture. 


\section{Chart 1}

\section{National Farm Income as a Percentage of National Income}

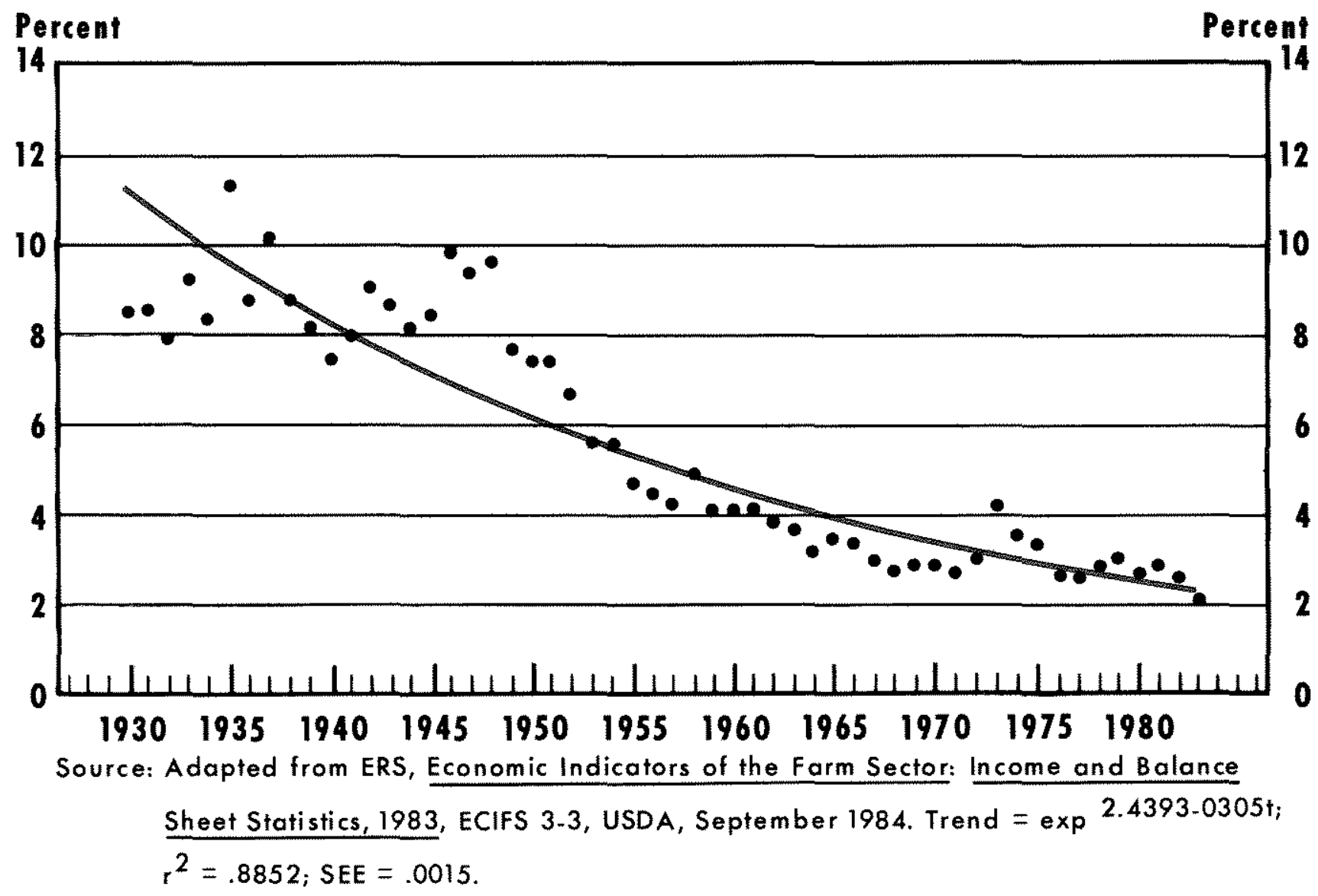

\section{AGPTCULTURE IN ECONOMTC DEVELOPNENT}

Perhaps nowhere in the world is the record of how agriculture affects and is affected by economic development more clearly revealed than in the United States. The key is in resources made surplus by increasing agricultural productivity. In market-led economic development, agriculture is told by chronically declining terms of trade that economic development requires a continuing diminution in the share of the nation's resources allocated to agriculture. This is what is revealed in the data of chart 1 . Since 1930, farm income as a percentage of national income has declined an average of 16 basis points per year. The trend now has flattened to a ratio of near 2 percent.
Half the explanation is found in secular increases in agricultural productivity. The process releases resources from primary production to other sectors and thus provides the necessary condition for economic growth and development. It also shifts supply curves for food commodities positively across demand curves that are low in price elasticity, thus explaining much of the price instability that is chronic for food commodities.

The other half of the explanation is found in Engel's Law. Engel's Law says that, as income increases, the proportion spent for food commodities decreases. Secular increases of income produce a continuing decline in the income elasticity of demand for food commodities. Income elasticities of demand for food 
commodities are near zero in the United States and other more-developed countries while still high in less-developed countries with low incomes.

Trendwise deterionation in agriculture's terms of trade does not imply a trendwise decline in the economic well-being of U.S. farmers. No one has a problem identifying the 1960s as more prosperous for U.S. farmers than the 1930s, despite observations below the declining trend in the 1960s. Owing to adjustments in response to the declining terms of trade, there are, trendwise, fewer farmers to share in the aggregate of farm income. Chart 1 also reveals positive as well as negative variations from the trend. Variations to either side create expectations all too readily capitalized into land values that then have lagged effects on the welfare of those who buy under such expectations.

There is little in these propositions that cannot be found four decades ago in T. W. Schultz' Agriculture in an Unstable Economy, and further elaborated wo decades ago by E. O. Heady, in Agricultural Policy Under Economic Development." Subsequent observations simply support the early insights they provided. What is new, especially in the past two decades, is the internationalization of the propositions, owing to the spread of agricultural technology, the consequent spread of economic development, and the conversion of closed economies into open economies, especially through the internationalization of financial markets.

\section{INTERNATIONAL ASPECTS OF U.S. AGRICULTUPE}

"The U.S. food and fiber system accounts for about one dollar in five spent in the United States. The farm component is only 13 percent of the system. The farm component and the system as a whole is thoroughly internationalized. Farmers buy from farm suppliers who sell into export markets as well as to farmers. Farmers share a U.S. domestic commodity market with foreign producers. As U.S. farmers sell into export markets, they compete with both local producers and producers in other exporting countries. International trade is managed by multinational firms, augmented by a complex of state and parastatal agencies.

The U.S. food and fiber system, farms included, are financed through financial markets that produce in

3See Schultz (1945) and Heady (1962).

${ }^{4}$ See Baker (1987). terest rates influenced by capital-intensive economic development in Asia and elsewhere, as well as in umban U.S.A. OUF own tight monetary and loose fiscal policies during the early 1980 s revealed consequences that spilled readily over national boundaries, affecting interest rates everywhere, and the exchange value of the U.S. dollar. Debt service burclens Third Word countries, influencing their demand for U.S. exports and threatening the solvency of international lenders, as the solvency of rural leaders is threatened by financially stressed U.S. farmers. We have one-world comnodity and financial markets. They transmit shocks that heavily influence the U.S. food and fiber' system and the economic welfate of frms, families and communities throughout the system.

A still smaller part of the food and fiber system is represented by research and development (R\&D), Yet agricultural R\&D, U.S. and elsewhere, has a tremendous impact on economic development. The impact is on the demand side as well as the supply side for agricultural commodities. Economic development requires an economic; surplus that can be tapped for investments to generate economic growth. In much of the developing world, as in 19 th century United States, agriculture is the likely source in which the surplus can be produced. Agricultural R\&D is the triggering mechanism. An economic surplus in agriculture is a necessary condition for economic development in countries still largely rural.

The sufficlent condition for economic development is using the surplus to develop other sectors in such ways as to generate continuing growth in per capita incomes. The demand for food commodities will follow. If comparative advantages are consistent with economic development outside agriculture, the demand will be for food imports. Indeed, this is the most promising remedy for the plague of chronic hunger, largely unabated in the world despite the well publicized, worldwide glut of food commodities.

\section{FINANCIAL MARKETS AND TRADE}

A significant consensus links the historic boom in U.S. farm commodities during the 1970s to increased demand for U.S. farm exports, triggered by the declining exchange values of the U.S. dollar in that decade. It was easy to argue, therefore, that the historic bust in U.S. farm commodities from 1981 through 1984 could be explained by the increasing exchange values of the U.S. dollar in that period. Since February 1985, the exchange values of the U.S. dollar have declined again - by nearly 50 percent with respect to the yen, for 
example. The puzzle is in the apparent failure of demand for U.S. exports to respond more readily than it has to this second reversal in the exchange value of the U.S. dollar.

Observations that fail to confirm predictions of widely accepted theory lead to questions on (1) the accuracy of the observations, (2) the assumptions and logic with which the theory is applied and (3) the theory itself. All three responses can be found in a burgeoning literature on exchange rates and trade.

In a recent doctoral dissertation, Dr. Dimitrios Baroutis found that, over the past two years, the U.S, dollar has not depreciated in terms of the currencies of competing wheat exporters, ${ }^{5}$ Deborah Olivier, in the Wall Street Journal, January 30,1987 , reported that the U.S. dollar had in fact appreciated by 35 percent with respect to currencies of countries that export "food and live animals."

In the same issue of the Wall Street Journal, Professor Ronald I. McKinnon noted that, over the two-year interval, exports from Japan had indeed declined, as predicted by the theory. But, owing to the negative effects on Japanese incomes, imports to Japan had declined still more. The result is the apparent paradox of an increasing trade surplus for Japan in the presence of an appreciating yen and a lagging response in Japan to lowered prices of imports from the United States. In a letter to the editor of the Wall Street Journal, dated February 2, 1987, Lawrence Kreicher of Irving Trust suggested that the appropriate question is "what would be the trade deficit had the dollar not been depreciated?" His calculations suggested about 15 percent higher than in fact it was over the two-year period.

Our capacity to explain the failure of $1985-1987$ to look like 1973-1980, or to reverse the adverse agricultural trade events of 1981-1984 is somewhat limited, even after correcting for possible errors in observations. There may be something to the common belief that institutional rigidities preclude the adjustments predicted by the theory to restore trade equilibrium. However, why did they not also preclude the previous sharp turning points in the early 1970 s and the early 1980s? There likely is much to the belief that positive supply shifts outside the United States for crops important in U.S. farm exports, at least in the short term, are irreversible. Insofar as the shifts occur in lowincome countries, the evidence suggests that subse-

${ }^{5}$ See Baroutis (1986).

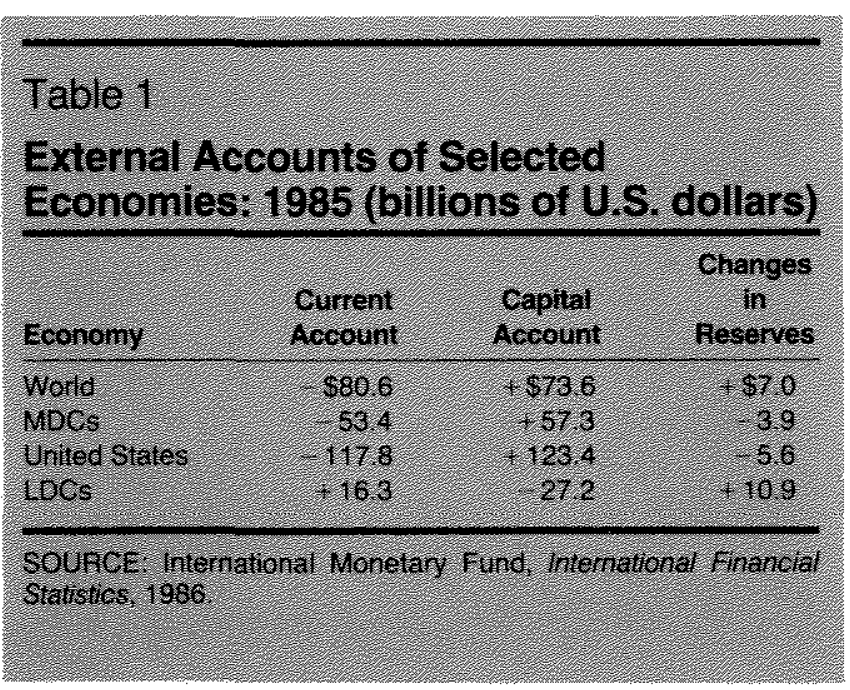

quent economic development will in fact ultimately increase the demand for U.S, farm exports, and thus, eventually will be a positive factor for U.S. agriculture.

Perhaps more important is the fact that our expectam tions rest on the heritage of a purchasing power parity (PPP) theory that focuses on adjustment processes in the current account, dominated by the trade balance, and emphasizing relative prices of tradeables between countries and of tradeables and nontradeables within countries. In 1985, the volume of commodity transactions in world trade was about \$U.S. 3.0 trillion. In contrast, the volume of world trade in financial assets was about $\$$ U.S. 110 trillion. The relative volumes suggest that trade in financial assets, reflected in the capital account, has come to dominate trade in goods and services as a source of change in exchange values of national currencies, and also adjustments to variations in those exchange rates.

To examine the capital account requires a brief digression into a simplified open-economy version of macroeconomics. The gross national product of an economy is given by:

$$
\mathrm{GNP}=\mathrm{C}+\mathrm{I}+\mathrm{G}+(\mathrm{X}-\mathrm{M})
$$

where $C$ equals consumption

I equals investment,

$\mathrm{G}$ equals net government expenditures,

$\mathrm{X}$ equals exports, and

$M$ equals imports.

$\mathrm{X}-\mathrm{M}$ is the trade balance, the principle component of the current account. $1=s$, savings. Much of savings for the United States occurs outside the United States. The resulting capital inflow produces a capital account that is highly positive: \$U.S. 123.4 billion in 1985 as shown in table 1. 
For any economy, the current account equals the capital account, plus or minus changes in reserves. Thus the large surplus on capital account for the United States contributes much of the offset for the large deficit on current account (minus \$U.S. 117.8 billion in 1985). Indeed the U.S. current account has been highly negative since 1981, the last year with. a positive trade balance. Two observations are important relative to table 1: (1) the LDCs (less-developed countries) in aggregate are running positive current accounts and, therefore, are flowing capital to the MDCs (more-developed countries), notably the United States, and (2) in 1986, the United States became the world's largest debtor nation.

Just as PPP focuses on commodity trade and prices, interest rate parity (IRP) centers on trade in financial assets, and on interest rates and exchange rates. PPP proposes that commodity prices respond to changes in currency values so as to leave unchanged the ratio of home to foreign price levels. IRP proposes that changes in home to foreign interest rate differentials leave relative currency values unchanged, owing to counter-balancing changes in expected inflation rates and risk premiums.

The appeal of IRP is supported by a logic that says financial assets are highly substitutable between jurisdictions of the financial assets and independent of the currencies in which they are denominated. ${ }^{6}$ The evidence suggests that, if denominated in the same currencies, differences in jurisdictions do not impede substitutions among financial assets. If denominated in different currencies, however, the differences in jurisdictions do appear to impede substitution among financial assets.

The most plausible explanation for this difference is in the risk premium. Despite large trade and fiscal deficits, the U.S. dollar persisted strong relative to the yen, the Deutsche mark, the British pound, etc. from 1981-1984. Currently, Japanese demand for U.S. financial assets has remained strong despite grievous losses associated with converting depreciating U.S. dollars into yen.

The disciplines enforced upon other countries in both the current account and capital account are restrained for the United States because of the unique role of the U.S. dollar in international relationships, notably in the denomination of international contracts related to commodity trading and of financial

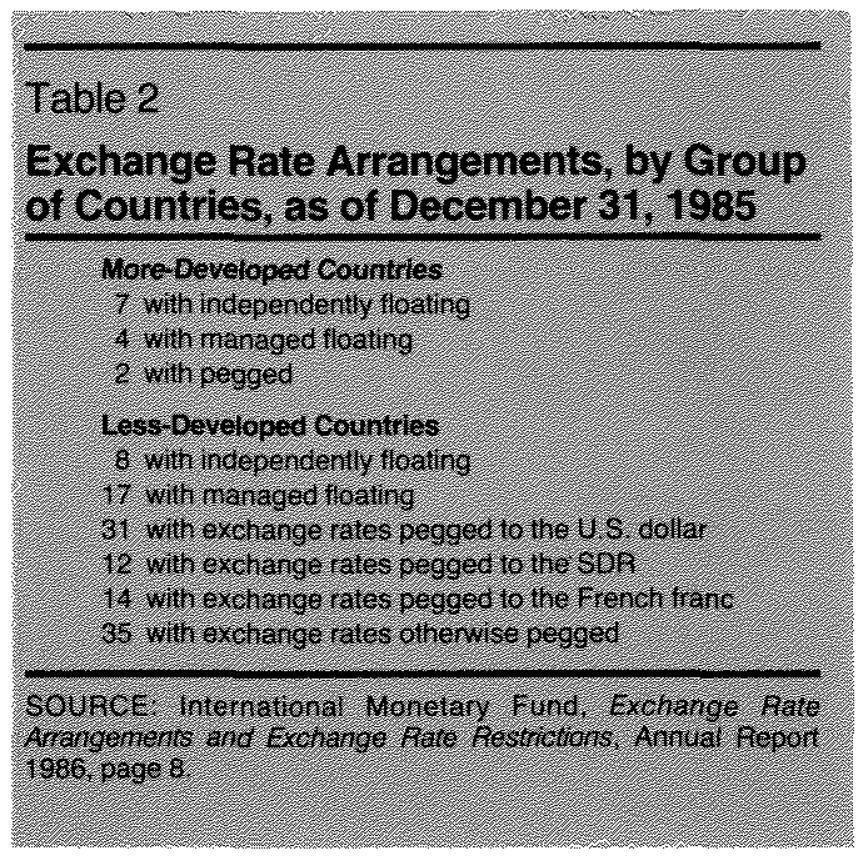

assets traded internationally. The U.S. dollar is the world's principal reserve currency. While a depreciating U.S. dollar does weaken its use as a reserve currency, there appears to be no readily available substitute at a relevant scale of use in international transactions.

\section{CURRENT EXCHANGE RATE ARRANGEMENTS}

Current exchange rate arrangements commonly are referred to as flexible. In fact, they consist of a combination of flexible, fixed and managed exchange rates. Among the currencies of the 148 members of the International Monetary Fund (IMF) on December 31, 1985, only 15 could be described as independently floating (see table 2$)^{7}$ These 15 , however, include such major currencies as those of Japan, the United Kingdom and the United States. An additional 31 countries have currencies that are pegged to the U.S. dollar.

The European Community (EC) has evolved the European Currency Unit (ECU), a basket of currencies that includes the currencies of France and West Germany as well as six other EC countries. Although the individual currencies do not float independently (beyond a range of 4.5 percent, the ECU does. Moreover, the currencies of 14 more countries are pegged to the French franc alone.

See Cooper (1986).

${ }^{7}$ See International Monetary Fund. 
The IMF's Special Drawing Right (SDR) also is a basket of currencies. It is based upon five national currencies (U.S. dollar, Deutsche mark, French franc, British pound and the Japanese yen. The currencies of 12 countries are pegged to the SDR. Thus 79 of the nearly 148 currencies of IMF members are pegged or otherwise closely related to the floating currencies of the United States, EC and Japan. Much of the world trade in both commodities and financial assets is transacted in these currencies.

\section{POLICIES THAT TARGET EXCHANGE RATES}

The monitoring role of the IMF frequently places it in a key position with respect to countries with problems in external accounts, notably external debts to be serviced or renegotiated. The exchange rate is a common policy target in conditionality programs of IMF, owing to the effect it has on adjustments reflected in the current account.

Both PPP and IRP suggest that a nominal devaluation, a remedy commonly suggested, is quickly offset by price changes for commodities and financial assets to restore the original parities in the absence of other macroeconomic measures. The other macroeconomic measures include controlled growth of domestic money and reduced fiscal deficits. But the size of the required reductions in fiscal deficits have been found by Kahn and Lizondo to depend on the policies adopted. ${ }^{9}$ It is larger if the deficit is reduced with increased taxes than if the deficit is reduced with decreased expenditures. If the deficit is reduced with decreased expenditures, the required reduction is less if targeted toward sectors producing tradeables than if targeted toward sectors producing nontradeables.

\section{THE GURRENT AGENDA}

It is an understatement to say that many important issues remain unresolved. There now is a clamor to return to fixed exchange rates. But there is little agreement on parities in which they are to be fixed - or disciplined. Some call for a return to a gold standard. But there is little agreement on values to assign to gold.

The number of currencies is less than the number of countries because of shared currencies among certain countries.

See Khan and Lizondo (1978).
Dependence upon the U.S. dollar as the de facto currency of wonld trade creates severe problems for the United States as well as other countries. Monetary policy to meet U.S. objectives is not always consistent with world needs in terms of U.S. dollars, International consequences of domestic monetary policies can and do feed back to the United States with net negative results.

But there is little agreement on an alternative. Countries with alternative currencies appear too small relative to the world to provide the liquidity required of a world trading currency. There also must be general acceptance of the reserve currency as a medium of exchange and store of value.

A potential altemative is the SDR. Much remains to be done, however, for the SDR to succeed as a world trading currency. It is not now widely used as a means of settling transactions. Govemments of member countries of the IMF are not soon likely to arrive at an agreement on terms that would provide for the trans fer of sovereignty required to make the IMF the world's "central bank."

The state of knowledge on how trade relates to exchange rates also remains at a primitive level. Much of what is thought to be known has been achieved with the use of models of commodity and financial markets that in retrospect are highly deficient. There has been a slow but hopeful movement from singlemarket partial equilibria to tradeables/non-tradeables markets in general equilibrium; from simple models of bilateral exchange rate determination to multilateral models that include capital flows and income determination; and, largely in the future, joint determina tion of exchange rates, trade balances and prices, linked with macroeconomic policy variables and information on the all-important time lags.

It is not surprising to discover that the modeling is complex. So is the system. So are the data requirements and the computing requirements. Yet progress is imperative as the international financial markets grow in size, integration and impact on capitalintensive sectors that are sensitive to exports. The problems are urgent, and progress toward their resolution is slow. Nowhere is this more evident than for U.S. agriculture.

\section{PEFERENCES}

Baker, C. B. Current Financial Stress: Sources and Structural Implications for US. Agriculture, W. I. Myers Memorial Lecture (Comell University, January 1987), p. 28. 
Baroutis, Dimitrios. Triangular Exchange Rate Parities and U.S. Wheat Exports, unpublished Ph.D. thesis (University of Illinois, Urbana-Champaign, 1986), p. 229.

Cooper, Richard N. "Macroeconomics in an Open Economy," Science, 233:4769 (September 12, 1986), pp. 1155-159.

Economic Research Service. Economic Indicators of the Farm Sector Income and Balance Sheet Statistics, EC IFS 3-3 (USDA, September 1984).

Heady, E. O. Agricultural Policy Under Economic Development (lowa State University Press, 1962), p. 682.

International Monetary Fund. Exchange Arrangements and Exchange Rate Restrictions, Annual Report 1986.
International Financial Statistics, 1986.

Khan, Mohsin, and J. Saul Lizondo. "Devaluation, Fiscal Deficits and the Real Exchange Rate," Economic Review, World Bank, 1:2 (January 1978), pp. 357-74.

Kreicher, Lawrence. Wall Street Journal, February 2, 1987.

McKinnon, Ronald I. Wall Street Journal, January 30, 1987.

Melichar, Emanuel. Agricultural Finance Data Book (June 1987), pp. 5 and 11.

Olivier, Deborah. Wall Street Journal, January 30, 1987

Schultz, T. W. Agriculture in an Unstable Economy (McGraw.Hill, 1945), p. 299. 